\section{References}

Blau, J. N., Harris, M., and Kennett, S. (1969). New England fournal of Medicine, 281, 873.

El-Ebiary, H. M. (1971). Rheumatology and Physical Medicine, 11, 100

Foley, J. M. (1969). New England fournal of Medicine, 281, 905.

Huppler, E. G., Schmidt, H. W., Devine, K. D., and Gage, R. P. (1956). American Review of Tuberculosis, 73, 52 .
Knox, D. L., Clark, D. B., and Schuster, F. F. (1967). Pediatrics, 40, 560. Pedersen, E. (1959). Brain, 82, 566 Saunders, W. H., and Lippy, W. H. (1959). Annals of Otology, Rhinology and Laryngology, 68, 830 .

and Laryngology, 68, 830.

Spillane, J. D., and Wells, C. E. C. (1964). Brain, 87, 1.

Williams, R. G. (1959). Fournal of Laryngology and Otology, 73, 161.

\title{
Lymphocyte Sensitization to Carcinoembryonic Antigen (Gold) with Special Reference to Multiple Sclerosis
}

\author{
E. J. FIELD, E. A. CASPARY
}

British Medical fournal, 1972, 4, 261-263

\begin{abstract}
Summary
Lymphocytes from patients with multiple sclerosis are sensitized to carcinoembryonic antigen (C.E.A.) in almost the same degree as are those from subjects with cancer. During pregnancy and the early puerperium there is an even higher degree of cellular sensitization to C.E.A. Patients with neurological diseases other than multiple sclerosis also show significant sensitization to C.E.A. though of less degree than do those with multiple sclerosis. Sensitization to C.E.A. is thus not specifically characteristic of cancer. The unexpected sensitization in multiple sclerosis may be associated with the pronounced degree of gliosis found in that condition.
\end{abstract}

\section{Introduction}

Lymphocytes from patients with malignant neoplasia are sensitized to encephalitogenic factor (E.F.)-a basic protein extractable from human brain (Caspary and Field, 1965). They are sensitized to an even greater degree to a similar protein which can be isolated from neoplastic tissue-cancer basic protein (Ca.B.P.) (Field and Caspary, 1970; Caspary and Field, 1971)and the reverse is true in patients with organic nervous disease, where lymphocyte sensitization to E.F. is in general greater than to Ca.B.P. A comparison has now been made with sensitization to carcinoembryonic antigen (C.E.A.; Gold and Freedman, 1965), which is extractable from cancer of the colon tissue and from fetal gut and has been claimed to be an antigen characteristic of human tumours. Since C.E.A. is in strictly limited supply this preliminary report is limited in scale but makes it clear that lymphocytes are sensitized to C.E.A. in a number of conditions including, rather unexpectedly, multiple sclerosis.

\section{Materials and Methods}

Blood lymphocytes were isolated from $10-15 \mathrm{ml}$ of venous blood by the method of Coulson and Chalmers (1967) as modified by Hughes and Caspary (1970) using carbonyl iron and methylcellulose. Six normal subjects, 11 pregnant and puerperal women, 5 cancer patients, 10 multiple sclerosis patients ( 3 active, 7 quiescent), 12 patients with other neurological diseases (stroke, syringomyelia, encephalitis, etc.), and 6 patients with general paralysis of the insane (G.P.I.) were studied.

\footnotetext{
Medical Research Council Demyelinating Diseases Unit, Newcastle
} General Hospital, Newcastle upon Tyne

E. J. FIELD, M.D., M.S., Professor of Experimental Neuropathology E. A. CASPARY, M.SC., Member of Scientific Staff
Cellular sensitization was measured by the macrophage electrophoretic migration method described by Field and Caspary (1970) and Caspary and Field (1971). In principle the method depends on the interaction of sensitized lymphocytes with antigen to liberate some material (involving protein synthesis (Caspary, 1971, 1972)) with the property of causing normal guinea-pig macrophages to travel more slowly in an electric field. The liberated material (macrophage slowing factor) may well be the same as macrophage inhibitory factor, which forms the basis of the widely recognized macrophage migration inhibition test (David et al., 1964) for delayed hypersensitivity (Bloom and Bennett, 1966).

In practice normal guinea-pig macrophages are raised by intraperitoneal inoculation of sterile liquid paraffin and removal of the cellular exudate 6-10 days later with heparinized Hanks's balanced salt solution. Since the $10-20 \%$ of lymphocytes which are present in the exudate may enter into a mixed lymphocyte reaction with human lymphocytes, the exudate is exposed to 100 rads of gamma-irradiation, which incapacitates (at least temporarily) normal non-sensitized guinea-pig lymphocytes from entering into a mixed reaction, so that only the one-way human versus guinea-pig remains and is taken into consideration in the control measurements. In carrying out an experiment, $0.5 \times 10^{6}$ of the lymphocytes to be tested were mixed with $10^{7}$ irradiated guinea-pig macrophages in $3.0 \mathrm{ml}$ of medium 199. This mixture constituted the control tube. Antigens were added in $0.1 \mathrm{ml}$ of medium 199 or saline to other tubes. The mixtures were incubated for 90 minutes at $20^{\circ} \mathrm{C}$ (room temperature) before macrophage migration time was measured.

In the present experiments C.E.A. was used in concentrations of $33 \mu \mathrm{g} / \mathrm{ml}$, so that $100 \mu \mathrm{g}$ was incorporated in $3.0 \mathrm{ml}$, the standard antigen concentration throughout the series of experiments. Although the antigen was not clear of a small amount of muco-polysaccharides it gave clear-cut reactions. Cancer antigen was the basic protein (Ca.B.P.) prepared by Dr. J. P. Dickinson from a cancer of the cervix according to the method of Caspary and Field (1971). All measurements were made "blind" in a Zeiss cell electrophoresis apparatus (cytopherometer). A detailed account of the experimental method with an original protocol in extenso was given by Caspary and Field (1971).

If $t_{c}=$ migration time of macrophages without antigen present, and $t_{c}=$ time when antigen is present, then if a macrophage slowing factor has been produced

$$
t_{e}>t_{c} \text { and } \frac{t_{c}-t_{c}}{t_{c}} \times 100
$$

is a measure of macrophage sensitization. It represents the percentage increase in migration time resulting from the macrophage slowing factor produced by antigen-lymphocytes interaction, and these percentage figures are those given in Tables I-VII. Each $t_{c}$ and $t_{c}$ value was calculated from the mean of 20 
observations, and Student's $t$ test was used to establish the significance of differences found. In practice, with the degree of scatter present in the hands of an experienced observer a difference of $2.5 \%$ is significant $(P<0.01)$.

\section{Results}

The results obtained with the three antigens in different groups of subjects are set out in Tables I-VIII. The subjects were not matched but covered much the same age range. Sensitization to E.F. in normal people (Table I) never exceeds $5.0 \%$ except where there has been special exposure to brain or its productsfor example, in workers constantly in contact with the material (Caspary and Field (1971). The figure for Ca.B.P. is in general 1 or $2 \%$ lower. The C.E.A. results in this small group of normal laboratory workers never exceeded $2 \cdot 7 \%$. Among normal pregnant women, on the other hand (Table II), C.E.A. values were raised significantly, and this continued until the end of the first week of the puerperium (the longest period followed) (Table III). Ca.B.P., on the other hand, did not give a high result in pregnancy or the puerperium either in the present small series or in the much larger series presented by Smith et al. (1972).

The small series of cancer patients (Table IV) gave moderately raised C.E.A. results though well below those produced by Ca.B.P. A patient who was suffering from acute lymphocytic leukaemia (Case 12) showed the low lymphocyte reactivity which has previously been reported in this condition (Field and Caspary, 1970). Two patients with well-marked active chronic psoriasis (Case 17) were tested and gave surprisingly high values to all three antigens.

TABLE I-Results obtained in Normal Subjects expressed in Percentages

\begin{tabular}{c|c|c|c|c}
\hline Subiect & Sex & Age & C.E.A. & Ca.B.P. \\
\hline A & F. & 24 & 0.2 & 0.6 \\
B & M. & 26 & 0.5 & $=$ \\
C & M. & 28 & 2.7 & 2.7 \\
E & F. & 48 & 1.7 & 2.0 \\
F* & M. & 51 & 1.1 & 3.9 \\
\hline
\end{tabular}

*Laboratory worker exposed to E.F. and with an E.F. value currently $5.9 \%$.

TABLE II-Results in Normal Pregnant Women expressed in Percentages

\begin{tabular}{|c|c|c|c|c|}
\hline Case No. & Age & Weeks & C.E.A. & Ca.B.P. \\
\hline $\begin{array}{l}1 \\
2 \\
3 \\
4 \\
5 \\
6 \\
7\end{array}$ & $\begin{array}{l}23 \\
25 \\
24 \\
23 \\
30 \\
31 \\
25\end{array}$ & $\begin{array}{r}6 \\
23 \\
23 \\
26 \\
29 \\
30 \\
32\end{array}$ & $\begin{array}{r}9.9 \\
8.7 \\
13.3 \\
7.8 \\
10 \cdot 2 \\
8.4 \\
10.7\end{array}$ & $\begin{array}{l}\overline{1.2} \\
\overline{1} \\
0.3 \\
1.3\end{array}$ \\
\hline
\end{tabular}

TABLE III-Results in Normal Puerperal Women expressed in Percentages

\begin{tabular}{c|c|c|c|c}
\hline Case No. & Age & Days & C.E.A. & Ca.B.P. \\
\cline { 2 - 3 } & 25 & 2 & $9 \cdot 8$ & -0.4 \\
8 & 23 & 7 & $11 \cdot 7$ & $0 \cdot 2$ \\
9 & 33 & 8 & $16 \cdot 1$ & $2 \cdot 1$ \\
11 & 34 & 8 & $15 \cdot 3$ & 0.8 \\
\hline
\end{tabular}

TABLE IV-Results in Cancer Patients and a Patient with Psoriasis expressed in Percentages

\begin{tabular}{c|c|c|c|c|l}
\hline Case No. & Sex & Age & C.E.A. & Ca.B.P. & \\
\hline 12 & F. & 18 & $2 \cdot 8$ & $0 \cdot 8$ & Acute lympholeukae- \\
\cline { 5 - 5 } 13 & F. & 56 & $9 \cdot 4$ & $14 \cdot 1$ & Carcinoma bronchus \\
14 & F. & 69 & $9 \cdot 2$ & $14 \cdot 1$ & Carcinoma antrum \\
15 & M. & 77 & $11 \cdot 9$ & $14 \cdot 0$ & Carcinoma bladder \\
16 & M. & 82 & $11 \cdot 0$ & $16 \cdot 1$ & Carcinoma prostate \\
17 & F. & 41 & $10 \cdot 8$ & $8 \cdot 4$ & Psoriasis \\
\hline
\end{tabular}

* Lymphocytes in acute lymphocytic leukaemia have previously been found to be non-reactive to antigens - for example, purified thyroid protein derivative of tuber-
culin, thyroid, as well as to Ca.B.P. and E.F. (Field and Caspary, 1970).
Patients suffering from multiple sclerosis (whether in an active or quiescent phase) showed raised values with C.E.A. of the same order as that seen among the cancer patients (Table V). These patients also showed the expected high values with Ca.B.P. and E.F., the latter in general being higher. While patients with other neurological diseases (Table VI) likewise showed raised figures with Ca.B.P. and E.F. (again with the latter higher) as has previously been reported (Field and Caspary, 1970), the values with C.E.A. were distinctly lower than in multiple sclerosis patients $(P<0.001)$ but clearly above normal $(P<0.001)$. One case of myasthenia gravis studied also showed values within the range for other neurological diseases. Six patients with long-standing (more than 25 years) neurosyphilis (G.P.I.) showed results with C.E.A. well above the range for other neurological diseases and inside that for multiple sclerosis (Table VII). A statistical analysis of the results with C.E.A. is given in Table VIII.

TABle v-Results in Multiple Sclerosis Patients expressed in Percentages

\begin{tabular}{|c|c|c|c|c|c|c|}
\hline Case No. & Sex & Age & C.E.A. & Ca.B.P. & E.F. & \\
\hline $\begin{array}{l}18 \\
19 \\
20 \\
21 \\
22 \\
23 \\
24 \\
25 \\
26 \\
27\end{array}$ & $\begin{array}{l}\text { F. } \\
\text { F. } \\
\text { F. } \\
\text { F. } \\
\text { F. } \\
\text { F. } \\
\text { M. } \\
\text { M. } \\
\text { F. } \\
\text { F. }\end{array}$ & $\begin{array}{l}15 \\
31 \\
31 \\
33 \\
39 \\
41 \\
44 \\
47 \\
49 \\
51\end{array}$ & $\begin{array}{r}6 \cdot 3 \\
9 \cdot 4 \\
7 \cdot 0 \\
9 \cdot 5 \\
9 \cdot 7 \\
11 \cdot 2 \\
6 \cdot 8 \\
7 \cdot 0 \\
8 \cdot 0 \\
6 \cdot 7\end{array}$ & $\begin{array}{l}1 \overline{15 \cdot 7} \\
14 \cdot 1 \\
14 \cdot 0 \\
15 \cdot 4 \\
15 \cdot 4 \\
12 \cdot 8 \\
\overline{-} \\
12 \cdot 8\end{array}$ & $\begin{array}{l}15 \cdot 1 \\
17 \cdot 7 \\
16.2 \\
15.1 \\
16 \cdot 1 \\
16.9 \\
15 \cdot 4 \\
16 \cdot 2 \\
13.2 \\
14 \cdot 4\end{array}$ & $\begin{array}{l}\text { Active } \\
\text { Active } \\
\text { Quiescent } \\
\text { Quiescent } \\
\text { Quiescent } \\
\text { Quiescent } \\
\text { Quiescent } \\
\text { Acute } \\
\text { Quiescent } \\
\text { Quiescent }\end{array}$ \\
\hline
\end{tabular}

TABLE VI-Results in Patients with Other Neurological Diseases but Excluding G.P.I. expressed in Percentages

\begin{tabular}{|c|c|c|c|c|c|c|}
\hline Case No. & Sex & Age & C.E.A. & Ca.B.P. & E.F. & \\
\hline $\begin{array}{l}28 \\
29 \\
30 \\
31 \\
32 \\
33\end{array}$ & $\begin{array}{l}\text { M. } \\
\text { M. } \\
\text { F. } \\
\text { F. } \\
\text { F. }\end{array}$ & $\begin{array}{l}16 \\
26 \\
46 \\
50 \\
54 \\
54\end{array}$ & $\begin{array}{l}4 \cdot 7 \\
1 \cdot 2 \\
3 \cdot 9 \\
4 \cdot 9 \\
4 \cdot 0 \\
4 \cdot 0\end{array}$ & $\begin{array}{l}\bar{z} \\
\bar{z}\end{array}$ & $\begin{array}{l}11 \cdot 5 \\
10 \cdot 2 \\
13.9 \\
15 \cdot 3 \\
13 \cdot 6 \\
13.6\end{array}$ & $\begin{array}{l}\text { Muscular dystrophy } \\
\text { Cerebral aneurysm } \\
\text { Myasthenia gravis } \\
\text { Pneumococcal enceph. } \\
\text { Zoster myelitis } \\
\text { Degenerative enceph. }\end{array}$ \\
\hline $\begin{array}{l}34 \\
35 \\
36 \\
37\end{array}$ & $\begin{array}{l}\text { M. } \\
M . \\
M .\end{array}$ & $\begin{array}{l}55 \\
56 \\
60 \\
61\end{array}$ & $\begin{array}{l}5 \cdot 0 \\
5 \cdot 3 \\
5 \cdot 1 \\
4 \cdot 8\end{array}$ & $\begin{array}{l}11 \cdot 6 \\
13 \cdot 6 \\
14 \cdot 2 \\
11 \cdot 5\end{array}$ & $\begin{array}{l}13 \cdot 9 \\
15 \cdot 8 \\
16 \cdot 1 \\
13 \cdot 7\end{array}$ & $\begin{array}{l}\text { Stroke } \\
\text { Syringomyelia } \\
\text { ? Jakob-Creutzfeldt } \\
\text { Prolapsed disc with }\end{array}$ \\
\hline $\begin{array}{l}38 \\
39\end{array}$ & $\begin{array}{l}\text { M. } \\
\text { F. }\end{array}$ & $\begin{array}{l}63 \\
65\end{array}$ & $\begin{array}{l}4.9 \\
4.9\end{array}$ & 二 & 14.5 & $\begin{array}{l}\text { Cerebression } \\
\text { Stroke }\end{array}$ \\
\hline
\end{tabular}

TABLE VII-Results in Patients with G.P.I.*

\begin{tabular}{|c|c|c|c|c|c|}
\hline Case No. & Sex & Age & C.E.A. & Ca.B.P. & E.F. \\
\hline $\begin{array}{l}40 \\
41 \\
42 \\
43 \\
44 \\
45\end{array}$ & $\begin{array}{l}\text { M. } \\
\text { M. } \\
\text { M. } \\
\text { M. } \\
\text { M. }\end{array}$ & $\begin{array}{l}49 \\
52 \\
66 \\
69 \\
76 \\
77\end{array}$ & $\begin{array}{l}6.9 \\
6.0 \\
5.6 \\
7.3 \\
6.2 \\
6.9\end{array}$ & $\begin{array}{l}\bar{Z} \\
\bar{z}\end{array}$ & $\begin{array}{l}15.2 \\
14.3 \\
16.2 \\
15.8 \\
16.2\end{array}$ \\
\hline
\end{tabular}

*Long standing cases (more than 25 years).

TABLE VIII-Statistical Analysis of Groups with respect to C.E.A.

\begin{tabular}{|c|c|c|c|c|}
\hline & & $t$ Test & $\begin{array}{c}\text { Degrees of } \\
\text { Freedom }\end{array}$ & $\mathbf{P}$ Value \\
\hline $\begin{array}{l}\text { Normal } v \text {. multiple sclerosis } \\
\text { Normal } v \text {. pregnancy } \ldots \\
\text { Normal } v \text {. cancer } \\
\text { Normal } v \text {. O.N.D. }\end{array}$ & $\begin{array}{l}\cdots \\
\cdots \\
\cdots \\
\cdots \\
\cdots \\
\cdots \\
\cdots \\
\cdots\end{array}$ & $\begin{array}{r}9 \cdot 1979 \\
8 \cdot 3463 \\
5 \cdot 0480 \\
5 \cdot 9099 \\
11 \cdot 3947 \\
6 \cdot 3375 \\
4 \cdot 2399 \\
2 \cdot 3289 \\
2.9007 \\
3 \cdot 9738 \\
1 \cdot 3686\end{array}$ & $\begin{array}{l}15 \\
16 \\
10 \\
17 \\
11 \\
21 \\
17 \\
15 \\
20 \\
16 \\
14\end{array}$ & $\begin{array}{l}<0.001 \\
<0.001 \\
<0.001 \\
<0.001 \\
<0.001 \\
<0.001 \\
<0.001 \\
0.05-0.025 \\
0.01-0.005 \\
0.005-0.001 \\
0.2-0.1\end{array}$ \\
\hline
\end{tabular}

O.N.D. = Other neurological diseases.

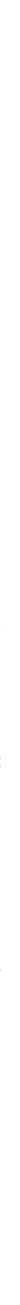




\section{Discussion}

While lymphocytes from patients with malignant disease show moderate lymphocytic sensitization to C.E.A., sensitization also occurs in pregnancy and the early puerperium (where it is higher than in cancer) as well as in multiple sclerosis and other neurological diseases, and especially in G.P.I. Antibody to C.E.A. during pregnancy was reported by Gold (1967). The cellular sensitization to C.E.A. in multiple sclerosis is difficult to explain, but since there is a moderate response in other neurological diseases also it is presumably related to some pathological process which is more developed in multiple sclerosis than in other neurological diseases. That which comes to mind is gliosis. Ever since Charcot (1872) wrote "without doubt [incontestablement] the increase in numbers of neuroglial nuclei and concomitant hyperplasia of the reticulated fibrils is the initial stage, the necessary antecedent [ . . . to demyelination]; the degenerative changes in nervous elements is secondary, consequential," there have been workers who have been struck by the glial proliferative changes in multiple sclerosis which seem out of all proportion to the needs of a simple reparative process (Müller, 1904). Some, indeed, like Charcot have seen glial hypertrophy as an initial stage in the development of multiple sclerosis lesions (Anton and Wohlwill, 1912; Field, 1967; Jacob, 1969). Gliosis is much less pronounced in most other neurological diseases.

An association with extent of parenchymatous destruction and gliosis is further suggested by the results obtained in the small series of patients with G.P.I. it was possible to include. Here too there was pronounced and widespread overgrowth of astroglia. Unfortunately insufficient C.E.A. was available to extend the study and to take in subacute sclerosing panencephalitis, which affords another instance of pronounced glial overgrowth. A difference between G.P.I. and other neurological diseases was also found by Field and Caspary (1972) when lymphocytes were tested against human thymus, the reaction in the former being greater than the latter. Again the cases of G.P.I. stood closer to multiple sclerosis than did other neurological diseases. These relations may depend on gliosis or they may be a consequence of the immunization which follows brain degradation and is more pronounced in G.P.I. and multiple sclerosis than in most other neurological diseases.

Two questions may be posed-( $a$ ) is the response to C.E.A. associated with active tissue proliferation (for example, in pregnancy), or with the increased mitosis in the skin occurring in psoriasis?; $(b)$ is the response to C.E.A. associated with a "semi-malignant transformation" of astroglial cells and thus equivalent to the moderately increased response to Ca.B.P. seen in precancerous conditions? (Field, 1967).
There is some evidence (chiefly biochemical) that multiple sclerosis is a widespread disease of the central nervous system. though the advanced focal changes which result in plaques are so striking that they attract attention almost exclusively. Disturbance of astroglia perhaps through long colonization by a "slow" infective agent might well lead to biochemical changes in seemingly normal white matter at a distance from lesions, while advanced dysfunction would result in histological demyelination. As a supply of C.E.A. becomes more easily available further studies may clarify and extend the observations here presented, especially with regard to the relation between gliosis and lymphocyte sensitization to C.E.A.

We are most grateful to Drs. A. M. Neville and C. W. Turberville, of the Chester Beatty Institute, London, for their generosity in letting us have samples of C.E.A.; to our colleagues of the Newcastle University Hospitals for access to patients under their care; to Dr. J. P. Childs, superintendent of St. Nicholas Hospital, Newcastle, for permission to study patients with G.P.I.; and to Mr. A. Keith and Mrs. J. Cunningham for technical help in the preparation of macrophages and lymphocytes. We are indebted to the North-eastern branch of the Multiple Sclerosis Society, and the Multiple Sclerosis Research Fund Ltd., for supplying the cytopherometers with which this work was carried out.

\section{References}

Anton, G., and Wohlwill, Fr. (1912). Zeitschrift für dir gesamte Neurologie und Psychiatrie, 12, 31.

Bloom, B. R., and Bennett, B. (1966). Science, 153, 80.

Caspary, E. A. (1971). Nature New Biology, 231, 24.

Caspary, E. A. (1972). Clinical and Experimental Immunology, 11, 305. Caspary, E. A., and Field, E. J. (1965). Annals of the New York Academy of Sciences, 122, 182.

Caspary, E. A., and Field, E. J. (1971). British Medical fournal, 2, 613.

Charcot, J. M. (1872). Leçons sur les Maladies du Système Nerveux, p. 239. Paris, Delacroix.

Coulson, A. S., and Chalmers, E. G. (1967). Immunology, 12, 417

David, J. R., Al-Askari, S., Lawrence, H. S., and Thomas, L. (1964). Journal of Immunology, 93, 264.

Field, E. J. (1967). Deutsche Zeitschrift für Nervenheilkunde, 192, 265.

Field, E. J., and Caspary, E. A. (1970). Lancet, 2, 1337.

Field, E. J. and Caspary, E. A. (1972). Journal of Neurology, Neurosurgery and Psychiatry. In press.
. In

Gold, P., and Freedman, S. O. (1965). Journal of Experimental Medicine, 121, 439.

Hughes, D., and Caspary, E. A. (1970). International Archives of Allergy and Applied Immunology, 37, 506.

Jacob, H. (1969). In Pathogenesis and Etiology of Demyelinating Diseases,

Müller, E. (1904). Die multiple sklerose des Gehirns und Ruckenmarks. Jena,

Fischer.
Smith, J. K., Caspary, E. A., and Field, E. J. (1972). American fournal of Obstetrics and Gynecology, In press..

\title{
Intermittent Secretion of Abnormal Bile in Patients with Cholesterol Gall Stones
}

\author{
R. A. SMALLWOOD, P. JABLONSKI, J. McK. WATTS
}

British Medical fournal, 1972, 4, 263-266

\section{Summary}

Gall bladder and hepatic bile was sampled from 66 patients undergoing elective operations on the biliary

\footnotetext{
Department of Medicine, Austin Hospital, University of Melbourne, Australia

R. A. SMALLWOOD, M.B., M.R.A.c.P., Wellcome Senior Research Fellow in Clinical Science

Department of Surgery, Prince Henry's Hospital, Monash University, Melbourne, Australia

P. JABLONSKI, M.SC., PH.D., N.H. \& M.R.C. Research Fellow

J. McK. WATTS, M.B., F.R.A.C.S., Professor of Surgery
}

tract. Fifty-one patients had cholesterol gall stones but only $59 \%$ of these were found to have bile which was supersaturated with cholesterol. Repeated sampling of hepatic bile from patients with $T$-tubes showed that the secretion of supersaturated bile was intermittent.

These results indicate that it is impossible to separate patients with cholesterol stones from controls simply by examination of the lipid composition of their bile, since an appreciable number of bile samples from patients with cholesterol stones were unsaturated.

The fact that cholesterol gall stones form when the bile is supersaturated with cholesterol only intermittently suggests that the gall bladder may also have a part in their formation. 